Jurnal Keislaman, Vol. 2, No. 1, Maret

\title{
ISLAMISASI SAINS DAN SEKULARISASI PENDIDIKAN DI INDONESIA
}

\author{
Nasiruddin ${ }^{1}$ \\ 01nasiruddin90@gmail.com \\ UINSA SURABAYA
}

\begin{abstract}
Abstrak: Sains masa lalu adalah pilar bagi tumbuh-kembangnya sains saat ini dan di masa mendatang yang memberikan andil pada terbentuknya sebuah peradaban manusia. Ilmu pengetahuan pada dasarnya tidaklah berkembang pada arah yang tak terkendali, tapi ia harus bergerak pada arah maknawi dan umat manusia berkuasa untuk mengendalikannya, salah satu alternatif yang ditawarkan oleh ilmuwan muslim adalah mengintegrasikan antara sains, filsafat bahkan agama yang lebih populer dengan istilah islamisasi sains sebagai suatu respon terhadap krisis masyarakat modern yang disebabkan oleh pendidikan Barat yang bertumpu pada suatu pandangan dunia yang bersifat materialistis dan sekularistik, Dunia pendidikan di Indonesia dalam arus peradaban manusia modern tidak akan pernah sunyi dari perubahanperubahan seiring dengan perkembangan ilmu pengetahuan dan teknologi.
\end{abstract}

Kata Kunci: Islamisasi Sains, Sekularisasi, Pendidikan, Indonesia

\section{A. PENDAHULUAN}

Kemajuan pesat dalam bidang ilmu pengetahuan atau sains menunjukkan betapa majunya daya nalar manusia dalam memanfaatkan potensi aqliah yang dianugerahkan Tuhan kepadanya. Sains masa lalu adalah pilar bagi tumbuhkembangnya sains saat ini dan di masa mendatang yang memberikan andil pada

\footnotetext{
${ }^{1}$ Mahasiswa Program Doktor IAIN Sunan Ampel Surabaya
} 
terbentuknya sebuah peradaban manusia. Ilmu pengetahuan pada dasarnya tidaklah berkembang pada arah yang tak terkendali, tapi ia harus bergerak pada arah maknawi dan umat manusia berkuasa untuk mengendalikannya.

Proses ilmu pengetahuan menjadi sebuah teknologi yang benar-benar dapat dimanfaatkan oleh masyarakat tentu tidak terlepas dari pencetusnya (ilmuwannya). Seorang ilmuwan akan dihadapkan pada kepentingankepentingan pribadi ataukah kepentingan masyarakat akan membawa pada persoalan etika keilmuan serta masalah bebas nilai (free values). Untuk itulah tanggungjawab seorang ilmuwan haruslah dipupuk dan berada pada tempat yang tepat, tanggung jawab akademis, dan tanggung jawab moral. Oleh karena itu, peran pendidikan dengan model-model yang dikembangkan harus mampu mendukung tercapainya revolusi pemikiran, untuk dapat mengejar ketertinggalan. Ini perlu diperhatikan karena sistem pendidikan yang diterapkan masyarakat muslim selama ini belum dapat mengakomodir kebutuhan dan tuntutan modernitas, apalagi penyelenggara pendidikan yang seringkali dualistik dengan memilih secara diamtetral antara ilmu umum dan agama. Pendidikan ideal seharusnya berparadigma integratif yang memposisikan sains secara proporsional. Sosialisasi paradigma sains yang manusiawi juga perlu mendapat porsi yang cukup dalam proses pendidikan, mulai dari pendidikan dasar sampai pendidikan tinggi. ${ }^{2}$

Oleh karena itu, salah satu alternatif yang ditawarkan oleh ilmuwan muslim adalah mengintegrasikan antara sains, filsafat bahkan agama yang lebih populer dengan istilah islamisasi sains sebagai suatu respon terhadap krisis masyarakat modern yang disebabkan oleh pendidikan Barat yang bertumpu pada suatu pandangan dunia yang bersifat materialistis dan sekularistik. Ini adalah salah satu penyebab penting bagi

2 Zaenal Habib, Islamisasi Sains: Mengembangkan Integrasi, Mendialogkan Perspektif, (UIN Malang Press, 2007). 92. 
munculnya suatu gerakan yang mencoba mengalihkan perhatian umat Islam dari nilai luhur agamanya yang selanjutnya merambah kedalam dunia pendidikan khususnya di Indonesia. Upaya pengembangan sains dan peradaban di dunia Islam secara garis besar dapat dilihat dalam hal berikut dalam Proyek Masa Depan Pengembangan Sains dan Peradaban Islam. ${ }^{3}$

Adapun Pusat Peradaban dan Islam ini berada pada paling pokok dan sebagai tujuan dari Akselerasi Perkembangan Sains dalam Masyarakat Muslim adalah Perkembangan Pemikiran dan Perubahan Paradigma. Sedangkan Perubahan paradigma meliputi Perubahan Cara Pandang Umat Islam Terhadap Sains, Model Pendidikan Ideal (Integrasi Sains dan Islam) Kebijakan Politik, Perubahan Masyarakat Muslim, Ide Islamisasi Sains dan Ide-ide lain.

Lalu yang menjadi permasalahan disini adalah Bagaimanakah integrasi sains dan Islam, bagaimanakah bentuk sekularisasi pendidikan di Indonesia dan bagaimana bentuk ideal integrasi sains dan Islam.

\section{B. HAKEKAT SAINS}

Dalam bahasa asing (Inggris), 'ilmu pengetahuan modern' disebut secara ringkas dengan istilah science yang dimelayukan di Malaysia dengan istilah sains dan yang di Indonesiakan sejak awal mula sudah diindonesiakan 'ilmu pengetahuan' untuk membedakan dari hasil upaya intelektual manusia yang tidak induktif, empirik dan indrawi. ${ }^{4}$ Para pengamat metodologi mengatakan bahwa sains adalah sistem

3 Zaenal Habib, Islamisasi Sains: Mengembangkan Integrasi, Mendialogkan Perspektif, (UIN Malang Press, 2007), 93.

4 . Soetandyo Wignjosoebroto dalam Perspektif Filosofis Integrasi Agama dan Sains, M. Zainudin dan M. In'am Esha (Editor), Horizon Baru Pengembangan Pendidikan Islam, (UIN press, Malang, 2004), 46. 
pernyataan-pernyataan yang dapat dikaji/diuji oleh siapapun dan dimanapun. Para pengamat heuristik akan menyatakan bahwa sains adalah perkembangan lebih lanjut bakat manusia untuk menentukan orientasi terhadap lingkungannya serta menentukan sikap terhadapnya. Sedang sebagian besar ilmuan mendefinisikan sains sebagai suatu hasil eksperimentasi, sehingga untuk mencapai suatu kebenaran harus melalui kesimpulan logis dan pengamatan empiris melalui metode ilmiah. ${ }^{5}$

Menurut Yuyun S. Suryasumantri sebagaimana dikutip Zainal Habib menyatakan bahwa hakekat sains secara internal mencakup pengetahuan tentang 'apa' yang dikaji oleh sains, 'bagaimana' cara sains melakukan pengkajian dan menyusun tubuh pengetahuannya serta 'untuk apa' pengetahuan ilmiah yang telah disusun itu dipergunakan. Dalam terminologi kefilsafatan, ketiga aspek pengkajian ini dikenal sebagai ontologi (apa), epistemologi (bagaimana), dan aksiologi (untuk apa). Disamping itu dicakup pula pembahasan mengenai sarana yang dipergunakan dalam proses pengkajian keilmuan seperti bahasa, logika, matematika atau statistik. Sedangkan secara eksternal pembahasan mengenai keberadaan sains dikaitkan dengan pengetahuan lain seperti moral, seni dan agama. ${ }^{6}$

\section{TITIK TEMU SAINS, FILSAFAT DAN AGAMA}

\section{Sains dan Agama (Islamisasi Sains)}

Sebagian besar literatur yang membahas hubungan antara agama (baca: islam) dengan sains menekankan; pertama, agama dimulai dengan keyakinan dan atau kekaguman, sementara sains dimulai dengan karaguan. Kedua, kebenaran ilmu bersifat relatif positif, sementara kebenaraan agama bersifat absolut. Ketiga, kebenaran sains diraih dengan eksperimental, sementara kebenaran agama dari Allah. Pernyataan-

\footnotetext{
${ }^{5}$ Ibid. 10.

${ }^{6}$ Ibid., 8.
} 
pernyataan tersebut sangat menarik dan sekaligus diyakini sebagai salah satu kebenaran sehingga menjadi kespakatan banyak pihak. Namun apabila ditelaah pernyataan tersebut mempunyai kelemahan-kelemahan: ${ }^{7}$

Pertama, ilmu pengetahuan dipahami sebagai proses dinamis untuk mencari kebenaran. Sementara agama bersifat statis dan dianggap kebenaran itu sendiri. Cara pandang terhadap agama semacam ini tentu saja tidak adil, karena untuk menemukan dan menggali kebenaran dalam agama juga harus melalui sebuah proses secara dinamis dan tidak akan pernah final. Kebenaran itu sendiri dapat dicapai melalui sebuah proses pencarian pengertian dan penafsiran sesuai dengan dinamika penafsiran manusia.

Kasus Nabi Ibrahim misalnya yang berusaha mencari kebenaran dan pengertian terhadap fenomena alam (fisika) dan akhirnya menemukan keyakinan yang paling dalam (spiritual) tentang adanya Tuhan. Upaya pencarian kenenaran dan pengertian itupun hanya akan melahirkan pengalaman keagamaan yang relatif, dan bukan kebenaran iru sendiri.

Kedua, konsep iman yang diartikan sebagai keyakinan itu sendiri, tetapi juga harus dipahami sebagai suatu proses dinamis untuk mendapatkan pengertian dan keyakinan terhadap apa yang diyakini itu. Sehingga percaya - sebagai terjemahan kata iman-bukan sebagai suatu proses final, melainkan sebagai starting point dari sebuah kepastian. Dalam proses pencarian ini, seorang yang beriman seharusnya juga ragu bukan ragu terhadap yang diimani melainkan ragu apakah keimananya sudah benar dan benar-benar iman? Pencarian keimanan harus menggunakan alat atau metode, yang bisa berupa filsafat ilmu. Maka dalam islam, iman harus dibuktikan dengan amal saleh. Namun amal saleh bukan semata manifiesasi iman, namun juga sebagai penguji

\footnotetext{
7 Zubaedi, Islam dan Bentuan Antarperadaban: Dialog Filsafat Barat dengan Islam, Dialog Peradaban dan Dialog Agama, (Yogyakarta: Ar-Ruzz, 2007), 127-130.
} 
kualitas iman. Dengan kata lain iman yang benar akan melahrkan amal saleh ysitu smsl ysng menyejahterakan masyarakatnya. Oleh karena itu, pada tataran ini agama dan sains bertemu. Keduanya perlu dipertemukan karena akan saling memperkuat.

Soetandyo Wignjosobroto dalam makalahnya mengutip kata-kata Albert Einstein bahwa agama tanpa bantuan ilmu pengetahuan akan lumpuh dan gagal mencapai tujuannya yang mulia, dan sebaliknya, ilmu pengetahuan tanpa bantuan agama akan buta dan gagal pula melihat tujuannya yang sejati. ${ }^{8}$ Arti agama dalam Islam diungkapkan dengan kata din, yang bukan sekedar konsep, tetapi merupakan ungkapan yang diterjemahkan amat baik ke dalam realitas, dan dihidupi dalam pengalaman manusia. $^{9}$

Ketiga, kebenaran yang mutlak pada dasarnya hanya satu, yaitu kebenaran Tuhan yang maha benar. Antara sains dan agama sama-sama menggali ayat-ayat kauniyah yaitu ayat-ayat yang tercipta baik berupa benda-benda biotik maupun abiotik termasuk didalamnya manusia. Ayatayat kauniyah tercipta memiliki hukum-hukum yang pasti atau relatif pasti yang disebut sunnatullah baik berupa postulat atau keteraturan dalam ilmu sosial maupun aksioma dalam ilmu eksakta. Secara epistemologi, memadukan sains dan agama Islam bisa dilakukan dengan islamisasi sains yaitu dari sisi metodologis. Agenda Islamisasi ilmu pengetahuan (Islamization of knowledge) pada dasarnya tidak berangkat dari epistemologi Islam, tetapi diadopsi dari ilmu-ilmu sekuler yang kemudian dikembangkan. Melalui islamisasi ilmu pegetahuan ini diharapkan dapat dilakukan evaluasi terhadap ilmu pengetahuan yang kurang atau tidak pas, mencakup seluruh ilmu pengetahuan (hasanah fi al-darain).

8 Lihat Horizon Baru Pengembangan Pendidikan Islam, Imam Suprayogo, Rekonstruksi Kajian Keislaman, M. Zainudin dan M. In'am Esha (Editor),Horizon Baru Pengembangan Pendidikan Islam, (UIN press, 2004), 45.

9. ibid., 22 
Sedangkan, Jika berorentasi pada asas aksiologi, maka pertemuan agama dan sains terjadi dimana sains digunakan: pertama, sebagai media untuk mengabdi kepada Allah. Kriteria sains yang berguna: ${ }^{10}$

1. Dapat meningkatkan pengetahuan seseorang akan Allah.

2. Efektif membantu mengemangkan masyarakat dan merealisasikan tujuan-tujuannya.

3. Dapat membimbing orang lain.

4. Dapat memecahkan berbagai problem masyarakat.

Dan kedua, agama Islam menjadi landasan pengembangan sains itu sendiri.

\section{Sains, Filsafat dan Agama}

Sains bisa ditinjau dari dua sisi yaitu filsafat dan agama. Mengenai dikotomi agama dan filsafat serta hubungan antara keduanya para pemikir terpecah dalam tiga kelompok: kelompok pertama, berpandangan bahwa antara keduanya terdapat hubungan keharmonisan dan tidak ada pertentangan sama sekali. Kelompok kedua, memandang bahwa filsafat itu bertolak belakang dengan agama dan tidak ada kesesuaiannya sama sekali. Kelompok ketiga, yang cenderung moderat ini, substansi gagasannya adalah bahwa pada sebagian perkara dan persoalan terdapat keharmonisan antara agama dan filsafat dimana kaidah-kaidah filsafat dapat diaplikasikan untuk memahami, menafsirkan dan menakwilkan ajaran agama.

Masyarakat modern telah berhasil mengembangkan ilmu pengetahuan dan teknologi canggih untuk mengatasi berbagai masalah hidupnya, namun pada sisi lain ilmu pengetahuan dan teknologi tersebut tidak mampu menumbuhkan moralitas (ahlak) yang mulia. Dunia modern saat ini, termasuk di indonesia ditandai oleh gejalah kemerosotan akhlak yang benar-benar berada pada taraf yang menghawatirkan.

\footnotetext{
10. Mahdi Ghulsyani, Filsafat- Sains menurut Alquran, terj. Agus Efendi, (Bandung, Mizan, 1990), 21.
} 
Kejujuran, kebenaran, keadilan, tolong menolong dan kasih sayang sudah tertutup oleh penyelewengan, penipuan, penindasan, saling menjegal dan saling merugikan. Untuk memahami gerak perkembangan ilmu pengetahuan dan teknologi yang sedemikian itu, maka kehadiran filsafat ilmu berusaha mengembalikan ruh dan tujuan luhur ilmu agar ilmu tidak menjadi bumerang bagi kehidupan umat manusia. Disamping itu, salah satu tujuan filsafat ilmu adalah untuk mempertegas bahwa ilmu dan teknologi adalah instrumen bukan tujuan. Dalam konteks yang demikian diperlukan suatu pandangan yang komprehensif tentang ilmu dan nilai-nilai yang berkembang di masyarakat.

Dalam masyarakat beragama (Islam), ilmu pengetahuan adalah bagian yang tak terpisahkan dari nilai-nilai ketuhanan karena sumber ilmu yang hakiki adalah dari Tuhan. Manusia adalah ciptaan Tuhan yang paling tinggi derajatnya dibandingkan dengan mahluk yang lain, karena manusia diberi daya berfikir, daya berfikir inilah yang menemukan teori-teori ilmiah dan teknologi. Pada waktu yang bersamaan, daya pikir tersebut menjadi bagian yang tak dapat dipisahkan dari keberadaan manusia sebagai mahluk Tuhan. Sehingga dia tidak hanya bertanggung jawab kepada sesama manusia, tetapi juga kepada pencipta-Nya.

\section{HAKEKAT SEKULARISME}

Istilah sekular, berasal dari kata latin saeculum, mempunyai arti dengan dua konotasi waktu dan lokasi: waktu menunjuk pada pengertian "sekarang atau kini" dan lokasi menunjuk kepada pengertian "dunia atau duniawi”. Jadi saeculum berarti zaman ini atau masa kini, dan zaman ini atau masa-kini menunjuk kepda peristiwa-peristiwa di dunia ini, dan itu juga berarti peristiwa-peristiwa masa-kini. Tekanan makna diletakkan pada suatu waktu atau periode tertentu di dunia yang dipandang sebagai suatu proses sejarah. Pengerian sekular menunjuk kepada kondisi dunia pada waktu, periode atau zaman tertentu ini. Sekularisasi didefinisikan sebagai pembebasan 
manusia pertama-tama dari agama dan kemudian dari metafisika yang mengatur nalar dan bahasanya. Itu berarti terlepasnya dunia dari pengertian-pengertian religius dan religiussemu, terhalaunya semua pandangan-pandangan dunia yang tertutup, terpatahkannya semua mitos supranatural dan lambang-lambang suci. Menurut sosiolog Jerman Max Weber yang dimaksudkan sekulerisasi ialah pembebasan alam dari noda-noda keagamaan; dan ini melibatkan penghalauan roh-roh animistis, tuhantuhan dan magis dari dunia yang alami, memisahkannya sehingga manusia tidak lagi memandang alam sebagai suatu wujud yang didewa-dewakan. ${ }^{11}$

Menurut Syekh Taqiyuddin An-Nabhani Sekuler adalah memisahkan agama dari kehidupan. Ada yang mengatakan juga bahwa sekuler adalah pemisahan agama dari politik. Akan tetapi makna yang kedua ini yang lebih populer di kalagan masyarakat. Karena memang munculnya istilah ini diawali dengan kasus pergulatan politik antara gereja dengan para kaum intelektual. ${ }^{12}$

Sekularisme adalah satu isme dalam kultur yang memiliki ciri sebagai berikut:

a. Secara sadar mengonsentrasikan atau memusatkan perhatian sematamata pada masalah duniawi.

b. Dengan sadar pula mengasingkan dan menyisihkan peranan agama, wahyu dan Tuhan dari pelbagai segi kehidupan. Islam dapat sejalan dengan sekularisme dalam hal sama-sama memperhatikan masalah duniawi. Akan tetapi, Islam secara prinsip menolak sekularisme karena yng terakhir ini dalam rangka memusatkan perhatiannya kepada masalah dunia itu, telah secara sadar memalingkan muka dari agama atau wahyu dan Tuhan dalam kehidupan sehari-hari. Umat Islam menentang sekularisasi karena sekularisasi adalah proses yang membawa orang, golongan, atau masyarakat

\footnotetext{
11 . Syekh Muhammad al-Naquib al-Attas, Islam Dan Sekularisme (Bandung: Perpustakaan Salman ITB, 1981), 20.

${ }^{12}$ Enjb.blog spot.com
} 
semata-mata berhaluan duniawi, kian lama kian memalingkan muka dri nilai-nilai norma-norma Ilahi yang abadi, kian lama kian memalingkan muka dari agama atau wahyu dan Tuhan ${ }^{13}$.

\section{E. GERAKAN SEKULARISASI PENDIDIKAN DI INDONESIA}

Sekularisasi dalam pendidikan merupakan satu proses menjadikan pendidikan tersebut sekuler. Yaitu adanya pemisahan antara pendidikan dengan agama. Sekuler dalam pendidikan bisa terjadi pada beberapa aspek. Di antaranya, pada metode, kurikulum dan media pembelajaran. Namun di sini penulis akan menitiberatkan pada sekuler dalam kurikulum pendidikan. Sekuler dalam kurikulum pendidikan di sini maksudnya adalah memisah-misahkan atau membatasi seseorang untuk mempelajari satu disiplin ilmu tertentu tanpa adanya kebebasan dalam menimba ilmu yang ada.

\section{Realita}

Pemisahan kurikulum pendidikan agama dan pendidikan umum yang ada menjadikan anak bangsa atau peserta didik tidak dapat menguasai ilmu berbagai bidang. Misalanya saja, dalam sebuah pembelajaran yang berbasis agama, di dalamnya tidak ada pendidikan umum yang kaitannya dengan teknologi. Begitu juga sebaliknya, pendidikan yang berbasis teknologi di dalamnya tidak diajarkan tata moral atau pendidikan agama. Inilah yang menyebabkan tidak adanya keseimbangan dalam diri peserta didik.

Kembali ke falsafah pendidikan, sebenarnya, kalau kita bongkar sampai ke akarnya, sekolah-sekolah yang diselenggarakan di negeri ini sudah salah sejak akarnya,

\footnotetext{
${ }^{13}$ Endang Saifuddin Anshari, Wawasan Islam: Pokok-Pokok tentang Paradigma dan Sistem Islam (Jakarta: Gema Insani, 2004), 183.
} 
yaitu soal konsep dasar dan falsafah pendidikannya. Sekolah-sekolah di negeri ini, sekalipun telah memiliki aturan perundang-undangan yang merancang pendidikan sejak basis pemikiran dasarnya sampai masalah-masalah pelaksanaan teknisnya, yaitu UU No. 20 tahun 2003 Tentang Sistem Pendidikan Nasional (Sisdiknas) dan peraturanperaturan turunannya, namun kelihatannya masih belum mencerminkan falsafah dan konsep pendidikan yang benar dan jelas. Walaupun dari sisi misi besar pendidikannya sudah bisa dibenarkan, namun turunan teknisnya justru tidak mencerminkan misi besar itu. Dalam UU Sisdiknas Bab I Pasal I disebutkan: "Pendidikan adalah usaha sadar dan terencana untuk mewujudkan suasana belajar dan proses pembelajaran agar peserta didik secara aktif mengembangkan potensi dirinya untuk memiliki kekuatan spiritual keagamaan, pengendalian diri, kepribadian, kecerdasan, akhlak mulia, serta keterampilan yang diperlukan dirinya, masyarakat, bangsa dan negara.” Bagian ini memperlihatkan tujuan dan sekaligus falsafah dari pendidikan yang harus diselenggarakan oleh semua lembaga pendidikan di Indonesia. Tidak ada yang bermasalah secara esensial kelihatannya. Apabila dilihat dari jumlah jam pelajaran disangsikan apakah kurikulum di sekolah-sekolah yang ada saat ini mampu mewadahi tujuan yang begitu luhur. Apalagi kalau kurikulum yang dijalankan dibedah sampai ke akar epistemologisnya. Akan segera semakin nyata ditemukan ketidakmungkinan kurikulum itu mengantarkan peserta didik sesuai dengan tujuan Sisdiknas di atas. Buktinya telah nyata di hadapan mata: secara moral kualitas keluaran pendidikan di negeri ini tidak menghasilkan pribadi-pribadi yang diharapkan! Kalaupun cerdas cenderung merusak. Kecerdasannya tidak mampu menemukan esensi kesejatian dirinya sehigga lahir pribadi-pribadi yang terpecah (split personality).

Kalau ditelaah lebih mendalam, memang kurikulum yang dikembangkan sebagai penjabaran dari misi sistem pendidikan nasional memperlihatkan ketidaksesuaian dengan misi besar sehingga hasilnya pun jauh dari apa yang 
diinginkan. Memang ada muatan agama yang wajib diajarkan di semua jenjang pendidikan seperti diamanatkan UU Sisdiknas pasal 37. Namun, kelihatannya keberadaan agama di sana tidak pernah memiliki kejelasan hubungan dengan pelajaran lain yang wajib dikembangkan seperti pendidikan kewarganegaraan, bahasa, matematika, ilmu pengetahuan alam, ilmu pengetahuan sosial, seni dan budaya, pendidikan jasmani dan olahraga, keterampilan/kejuruan, dan muatan lokal.

Agama bukan diletakkan sebagai ruh dari semua mata pelajaran yang ada. Agama memiliki ruang tersendiri, sementara pelajaran lain berada di tempat yang lain lagi. Keterpisahan ini semakin menegaskan ada paradigma keliru yang melandasi struktur kurikulum dan proses penyelenggaraannya dalam sistem pendidikan nasional di negeri ini. Kekeliruan ini berakibat fatal, yaitu krisis dan kegagalan pendidikan seperti yang kita saksikan hari ini. Mengenai pelajaran agama, baik Islam, Kristen, Katolik, ataupun agama lainnya, dalam Standar Isi di semua jenjang pendidikan, disebutkan kepentingannya bahwa pendidikan agama dimaksudkan untuk peningkatan potensi spiritual dan membetuk peserta didik agar menjadi manusia yang beriman dan bertakwa kepada Tuhan Yang Maha Esa dan berakhlak mulia. Akhlak mulia mencakup etika, budi pekerti, dan moral sebagai perwujudan dari pendidikan agama. Peningkatan potensi spiritual mencakup pengamalan, pemahaman, dan penanaman nilai-nilai keagamaan, serta pengamalan nilai-nilai tersebut dalam kehidupan individual ataupun kolektif kemasyarakatan. Peningkatan potensi spiritual tersebut pada akhirnya bertujuan pada optimalisasi berbagai potensi yang dimiliki manusia yang aktualisasinya mencerminkan harkat dan martabatnya sebagai makhluk Tuhan.

Dalam kasus agama lain boleh jadi benar bahwa agama hanya sekadar instrumen untuk membangun budi pekerti dan kualitas mental individual sejenisnya. Namun, bila dikaitkan dengan Islam, konsep ini tentu bermasalah. Islam tidak dapat didefinisikan hanya sekadar agama yang bertujuan membangun akhlak mulia dan budi 
pekerti semata. Islam memiliki dimensi sosial, politik, budaya, dan peradaban yang inheren dalam seluruh ajarannya. Mereduksi Islam hanya semata aspek spiritual adalah tindakan yang sangat gegabah dan "patut dicurigai" terkontamisasi pemikiran Baratsekular. Islam adalah suatu sistem yang komprehensif yang mencakup seluruh aspek dalam kehidupan manusia. Islam sangat memperhatikan aspek mentalitas dan kepribadian sebagai basis tindakan individual adalah benar. Namun pada saat yang sama Islam pun agama yang sangat menaruh perhatian besar pada masalah fisik manusia, sistem sosial, sistem hukum, kekuasaan, kebudayaan, bahkan kesenian sekalipun. Islam sama sekali bukan sematamata masalah spiritualitas. Kalau kenyataannya penjabaran sistem pendidikan nasional di negeri ini seperti jelas terbaca dalam Peraturan Menteri di atas yang akan menjadi acuan pembuatan kurikulum bagi seluruh sekolah di Indonesia, sudah tidak bisa ada interpretasi lain bahwa pengaruh pemikiran sekular sangat berpengaruh dalam sistem pendidikan Indonesia. Kekhasan pemikiran sekular terletak cara pandang terhadap agama. Agama diletakkan hanya sebagai urusan privat, dalam hal ini pembinaan mental-spiritual, bukan pada ranah publik. Agama telah diamputasi dan dikebiri; dimasukkan dalam satu kotak tersendiri dan kehidupan berada pada kotak yang lain. Dalam urusan pengaturan kehidupan, sosial kemasyarakatan, agama (Islam) ditinggalkan. Akibatnya, di tengah-tengah sistem sekuleristik tadi lahirlah berbagai bentuk tatanan yang jauh dari nilai-nilai agama. Yakni tatanan ekonomi yang kapitalistik, perilaku politik yang oportunistik, budaya hedonistik, kehidupan sosial yang egoistik dan individualistik, sikap beragama yang sinkretistik serta paradigma pendidikan yang materialistik.

Sementara itu, sistem pendidikan yang materialistik terbukti telah gagal melahirkan manusia saleh, berkepribadian mulia yang sekaligus menguasai ilmu, pengetahuan, dan teknologi (IPTEK). Secara formal kelembagaan, sekulerisasi pendidikan ini telah dimulai sejak adanya dua kurikulum pendidikan keluaran dua 
departamen yang berbeda, yakni Departemen Agama dan Departemen Pendidikan Nasional. Terdapat kesan sangat kuat bahwa pengembangan ilmu-ilmu kehidupan (IPTEK) adalah suatu hal yang berada di wilayah bebas nilai, sehingga sama sekali tak tersentuh standar nilai agama. Kalaupun ada hanyalah etik-moral (ethic) yang tidak bersandar pada nilai agama. Sementara, pembentukan karakter siswa yang merupakan bagian terpenting dari proses pendidikan justru kurang tergarap secara serius.

\section{F. UPAYA INTEGRASI SAINS DAN AGAMA DALAM MENANGKAL GERAKAN SEKULARISASI PENDIDIKAN DI INDONESIA.}

Dalam hubungan agama dan ilmu pengetahuan, secara garis besar terdapat dua pandangan yang berkembang di Indonesia, tetapi kedua-duanya belum diwujudkan dalam usaha yang serius dan terus menerus. Sebagian pandangan berasumsi bahwa ilmu pengetahuan sebagai produk dari kegiatan ilmiah bersifat netral (bebas nilai). Meskipun lahir dan berkembang dalam masyarakat Barat yang sekuler, ilmu pengetahuan sebagaimana adanya dapat digunakan untuk kepentingan umat manusia. Kaum muslimin dengan jiwa keislamannya yang mantap dapat menggunakan ilmu pengetahuan itu dan dijamin tidak akan hanyut dalam arus sekularisasi. Dalam konteks ini, gagasan islamisasi dipandang sebagai sikap apriori (kecemasan), semata-mata karena ilmu pengetahuan modern dikembangkan oleh ilmuan-ilmuan Barat. ${ }^{14}$

Tahap yang cukup signifikan dalam Islamisasi ilmu pengetahuan adalah usaha membangun basis-basis keislaman yang tangguh untuk semua disiplin ilmu. Usaha ini biasa disebut dengan Islamisasi disiplin ilmu (Islamization of diciplines). Daripada mempersoalkan aspek-aspek filosofis ilmu pengetahuan secara mendasar, islamisasi

\footnotetext{
14. Husni Rahim dalam “UIN dan Tantangan Meretas Dikhotomi Keilmuan”, M. Zainudin dan M. In'am Esha (Editor), Horizon Baru Pengembangan Pendidikan Islam,( UIN press, 2004). 52.
} 
disiplin ilmu lebih langsung menangani secara kritis teori-teori ilmu pengetahuan yang sudah berkembang. Keseriusan usaha ini terletak pada proses seleksi, identifikasi dan klasifikasi teori-teori yang relevan dan tidak relevan dengan Islam. Dengan demikian, penggunaan dalil-dalil keagamaan tidak selalu untuk mengabsahkan teori yang ada, tetapi juga untuk menolak dan sekaligus menawarkan alternatif terhadap teori yang berlawanan dengan ajaran Islam proses ini secara otomatis ikut memperkaya teori-teori ilmu pengetahuan itu sendiri dengan munculnya berbagai versi (mazhab). ${ }^{15}$

Dunia pendidikan di Indonesia dalam arus peradaban manusia modern tidak akan pernah sunyi dari perubahan-perubahan seiring dengan perkembangan ilmu pengetahuan dan teknologi. Indonesia yang notabenenya berpenduduk muslim terbesar di dunia adalah negara berkembang yang masih berada dalam posisi memanfaatkan atau menerapkan teknologi yang yang tidak lain merupakan produk dari pesatnya perkembangan ilmu pengetahuan yang dikembangkan Barat. Salah satu dampak psikologis yang paling dirasakan oleh semua kalangan adalah umat Islam tampaknya sedang mengidap penyakit kurang percaya diri dan psimistis (syndrom of inferiority complex), sebagai akibat adanya kemunduran peradaban Islam dibandingkan dengan peradaban Barat yang lebih maju. Menurut Suprayogo, untuk mendekonstruksikan atas dikotomi keilmuan telah mengharuskan adanya langkah penting untuk melakukan upaya rekonstruksi keilmuan Islam. Menurutnya, kita perlu untuk mencontoh kepada Ibnu Rusyd. Dialah tokoh yang telah memberikan perhatian berilian bagi kesatuan antara filsafat yang bersifat rasionalistik dan agama yang bersifat doktriner. Adapun alternatif yang dapat ditawarkan dalam upaya merekonstruksi kajian islam tetap memposisikan al-Qur'an dan al-Hadits sebagai sumber pokok yang tidak boleh dilewatkan. Menurutnya Al-Qur'an dan hadits berisi ajaran yang sedemikian

${ }^{15}$. Ibid., hlm. 53. 
luasmenyangkut beberapa persoalan, yaitu: 1). Ketuhanan, 2). Penciptaan, 3). Manusia dan perilakunya, 4). Alam dan sifat-sifatnya, dan 5). Keselamatan manusia dan alam. 16

Pengembangan pendidikan Islam ke depan secara realistis menurut H. A. Malik Fadjar, harus disinkronisasikan dengan kebijakan pendidikan nasional guna membebaskan bangsa dari himpitan berbagai persoalan. Beberapa hal mengenai prinsip-prinsip strategis pengembangan itu, antara lain:

1. Orientasi pengembangan sumber daya manusia.

2. Orientasi ke arah pendidikan Islam multikulturalis.

3. Mempertegas misi 'li utammima makarima al akhlaq'.

4. Spritualitas watak kebangsaan, fondasi dari bangunan kebangsaan itu menurut persepektif Islam adalah iman. ${ }^{17}$

Upaya-upaya strategis dalam Islamisasi sains baik yang ditawarkan H. A. Malik Fadjar dan Imam Suprayogo akan bermuara pada adanya satu langkah sistematis dan komprehensif yang harus disosialisasikan untuk tercapainya sebuah peradaban Sains Islami di masa depan. Dalam merangkum pendapat-pendapat di atas, maka sedikitnya ada tiga strategi besar sebagai master plan yang bisa ditawarkan dalam merealisasikan perubahan menuju peradaban Sains Islami dalam konteks keindonesiaan saat ini dan di masa depan yaitu:

1. Kebijakan pemerintah terhadap pendidikan.

2. Membangun dan mengembangkan lembaga-lembaga pendidikan atau Institusi yang Islami.

\footnotetext{
${ }^{16}$. Imam Suprayogo, Rekonstruksi Kajian Keislaman, M. Zainudin dan M. In'am Esha (Editor),Horizon Baru Pengembangan Pendidikan Islam, (UIN press, 2004). 21

17. H. A. Malik Fadjar, dalam Strategi Pengembangan Pendidikan Islam dalam Era Globalisasi (Pendahuluan), M. Zainudin dan M. In'am Esha (Editor), Horizon Baru Pengembangan Pendidikan Islam, (UIN press, 2004). xx-xxi.
} 
3. Dekonstruksi dan reorientasi disiplin-disiplin ilmu Islami dan modern.

\section{G. PENUTUP}

1. Islamisasi Sains pada dasarnya adalah memberikan nilai bagi perkembangan dan kemajuan ilmu pengetahuan dan teknologi.

2. Paham sekuler menjalar ke dunia pendidikan di Indonesia, sehingga diperlukan suatu upaya yaitu dengan mengedepankan misi islamisasi ilmu pengetahuan ke dalamnya.

3. Upaya strategis yang mungkin diterapkan sebagai gerakan Islamisasi sains sebagai salah satu bentuk alternatif peradaban manusia masa depan di Indonesia adalah:

a) Kebijakan pemerintah diusahakan berpihak terhadap islamisasi sains ke dalam dunia pendidikan dari tingkat dasar sampai perguruan tinggi.

b) Membangun dan mengembangkan lembaga-lembaga pendidikan atau Institusi yang Islami.

c) Dekonstruksi dan reorientasi disiplin-disiplin ilmu Islam dan sains modern.

\section{DAFTAR PUSTAKA}

- Chaedar Al-Wasilah, Filsafat Bahasa dan Pendidikan, Remaja Rosdakarya, Bandung, 2008.

- Endang Saifuddin Anshari, M.A, Wawasan Islam: Pokok-Pokok tentang Paradigma dan Sistem Islam, Jakarta: Gema Insani, 2004.

- http://www.enjb.blog spot.com/2009 
Jurnal Keislaman, Vol. 2, No. 1, Maret

- Husni Rahim, dalam UIN dan Tantangan Meretas Dikhotomi Keilmuan, M. Zainudin dan M. In'am Esha (Editor), Horizon Baru Pengembangan Pendidikan Islam, UIN press, 2004.

- Khudori Soleh, Wacana Baru Filsafat Islam, Pustaka Pelajar, Yogyakarta, 2004.

- M. Zainudin dan M. In'am Esha (Editor), Horizon Baru Pengembangan Pendidikan Islam, UIN press, Malang, 2004

- Mahdi Ghulsyani, Filsafat- Sains menurut Alquran, terj. Agus Efendi, Bandung,Mizan, 1990.

- Syekh Muhammad al-Naquib al-Attas, Islam Dan Sekularisme, Bandung:Perpustakaan Salman ITB, 1981.

- Soetriono dan Rita Hanafie, Filsafat Ilmu dan Metodologi Penelitian, Andi Offset, Yogyakarta, 2007.

- Sulaiman Nordin (Penyunting), Sains Menurut Persepektif Islam, Dwi Rama,2000.

- Zaenal Habib, Islamisasi Sains: Mengembangkan Integrasi, Mendialogkan Perspektif, UIN Malang Press, 2007.

- Zubaedi, Islam dan Bentuan Antarperadaban: Dialog Filsafat Barat dengan Islam, Dialog Peradaban dan Dialog Agama, Yogyakarta: Ar-Ruzz, 2007. 